\title{
WHAT DID MATTHIEU BEROALD TRANSMIT TO FRANÇOIS BÉROALDE DE
}

VERVILLE?

\section{NEIL KENNY}

We understand much about the ways in which texts and the knowledge they contained were transmitted in the early modern period. But we understand less about how the transmission of texts and knowledge related to other kinds of transmission. Families helped give social status to their members by passing on tangible goods (wealth and property) and less tangible ones (such as name and reputation). How did textual transmission fit in with that broader process? I explore that question in relation to the Calvinist scholar Matthieu Beroald and his son François Béroalde de Verville. The attempt draws gratefully on Stephen Bamforth's pioneering work on François.

What, in a nutshell, did Matthieu transmit to François, formally and informally? The orphan Matthieu, born in about 1523 and son of a barber-surgeon (Simon Brouart), had been taken under the wing of a maternal relative at the Collège du Cardinal Lemoine - François Vatable, who later became the inaugural royal Professor of Hebrew. Vatable apparently got Matthieu to replace 'Brouart' with 'Beroaldus', a name that his own son François would subsequently augment further. Matthieu ended up as Professor of Philosophy at the Geneva Academy, where he died in 1576. François was born in $1556 .{ }^{1}$

In terms of wealth and material assets, Matthieu seems to have bequeathed very little to François. The testament that an ailing Matthieu wrote during the siege of Sancerre in September 1572 stated that almost all of his assets were in Montargis (the town some 100 kilometres south of Paris that was a Huguenot haven, thanks to Renée, duchess of Ferrara, and where Matthieu had left his family). The testament stipulates that those assets should be sold and the proceeds shared equitably between Matthieu's second wife (Jeanne 
Pasquier) and the children from his first and second marriages, including his eldest son 'François Beroald'. Matthieu's first marriage produced three children and his second six. His testament's phrasing implies that the legacy is modest ('a fin qu'ilz ayent de quoy subvenir à leurs necessitez'). ${ }^{2}$ After Matthieu's eventual death four years later, the twenty-year-old François did inherit unknown assets. But at the age of twenty-seven he gave them all away to his three surviving siblings - his half-sisters Marie, Anne and Renée - aged from about ten to sixteen. ${ }^{3}$ Whatever the reasons for this gift - at a time when François seems to have attracted patronage $^{4}$ and when the girls, who had been orphans for seven years, probably had few other resources - it is likely that it left François himself wholly reliant on any income he could generate.

Another vital, if less tangible, instruction to executors in Matthieu's will was that his son François should persist with his studies: 'que l'on fasse estudier françois Beroald [...]'.5 Matthieu had already transmitted much learning to François both directly and indirectly, as Vatable had done previously to Matthieu. Direct transmission occurred for example through the early education given by Matthieu to François (and others) at Matthieu's home. That it was a remarkable education is suggested by the fact that three of these pupils ended up as major writers: L'Estoile and Agrippa d'Aubigné as well as François. More indirectly, it is probable that François studied at some of the institutions at which his father had taught between 1562 and 1572, though François's life over this period, between the ages of about six and sixteen (he was born in 1556), was extremely disrupted because of his family's flights from religious persecution. Unlike both his father and his quasi-grandfather Vatable, he never had the experience of spending several years immersed as a learner and then as a teacher in the same institution. Whether because of temperament or those circumstances, François's social status was not grounded throughout his life in institutions of learning, in the way that his father's and Vatable's had been. It would certainly be grounded in learning and literature, 
but often without the regular income, the official titles and the regimented, as well as transferable status-recognition, that institutions provided. A sign of reluctance to adopt the behavioural discipline required by one institution in particular is the trouble François got into with the Genevan Consistory when, aged about twenty-one, he was even imprisoned and, for a few months, denied the sacrament of the Lord's Supper. ${ }^{6}$

It is unknown whether Matthieu's stipulation that François should be made to study was respected after Matthieu's death in 1576, when François was twenty. As Stephen Bamforth has shown, François may have studied medicine around then, probably in Basel. ${ }^{7}$ If he did, then he was picking up the mantle that Vatable had wanted to put on the shoulders of François's father, Matthieu. ${ }^{8}$ François certainly possessed several medical volumes and his published work displays medical interests, but mainly later on (for example in 1612 when he also describes himself as having conducted a quasi-medical investigation in the early $1580 \mathrm{~s}) .{ }^{9}$ However, it is striking that the earliest of the several known occasions on which he was referred to by others in print as a doctor of medicine or even as a physician was in $1607 .{ }^{10}$ It seems unlikely that a man so careful about his name and titles would have refrained from using this one until his fifties if he had had the official right to do so. It is more likely that any medical studies stopped short of a doctorate and possibly even of a baccalaureate. ${ }^{11}$ By the time he was in his fifties and sixties and living (in Tours) a long way from Basel (and Geneva), his claim to be doctor of medicine seems to have been plausible enough to figure in two notarial documents, whatever its literal accuracy. ${ }^{12}$ It had after all been bolstered since 1607 by other people's references to him in print as a physician. Presumably less plausible, given that, as an apparent one-off, it did not stick, was the reference to him in a 1602 lease agreement as having a degree in law ('licancyes es loix'): no other evidence supports or even suggests this. ${ }^{13}$ 
Whatever the lost facts about any professional medical status that François may have acquired institutionally, he chooses to represent instead his early, medical-related training in terms of his frequenting a non-institutional world of alchemical practitioners, which led him to other kinds of artisans (clockmakers and goldsmiths). ${ }^{14}$ Much of his work is characterized by this interest in artisanal practices, both within alchemical medicine and beyond (notably in mechanics ${ }^{15}$ ), and by a presentation of himself as a kind of artisan. He frequently emphasizes, to a degree unusual for someone with his wide range of theoretical philosophical interests, the epistemological importance of manual techniques and thus their prestige. ${ }^{16} \mathrm{Within}$ medicine, he emphasizes - again to an unusual degree for someone eventually claiming to have a doctorate - the inseparability of theory from practice and the need for doctors to respect the know-how of surgeons. ${ }^{17}$ All this seems far from his father's areas of expertise in philology or Aristotelian dialectic and natural philosophy. However, the milieu in which Matthieu's own father lived for the first six or more years of his own life was emphatically artisanal. It is difficult to imagine that this left no traces in Matthieu, even if none are evident from his own published work (far less voluminous than that of his son). And Matthieu had early-years familiarity with the world of surgeons (before later studying medicine). It is possible that François picked up this artisanal-medical outlook and interest from his father and, unlike him, incorporated it into his writing.

So Matthieu may well have passed on to François not only a familiarity with a wide range of learning but perhaps also, intentionally or not, an interest in and respect for artisanal techniques. François used both these strands - to differing extents at different times of his life - to try and shape his social status and earn a living. Those attempts were more fluid, more precarious and mostly less institutional than his father's progress up the social scale. Poverty overwhelmed François for a long time, according to his early posthumous biographer Guillaume Colletet (whose predilection for the topos of unrecompensed literary merit should 
not make one discount it entirely as a window onto François's experience). ${ }^{18}$ The successive phases of François's career can be roughly divided into (i) using his learning to enable publishers to publish, with theoretical underpinning, the work of two other people (an artisan and an engineer); (ii) seeking patronage from royal office-holders - with mixed success and ultimate disillusion - by composing works that popularized a wide range of philosophy; (iii) writing more commercially for booksellers while also receiving a prebend as a cathedral canon in Tours; (iv) probably no longer being a canon, publishing less (but still on a wide range of topics including crafts) and popping up occasionally as an alchemist at court. ${ }^{19} \mathrm{He}$ was probably an (unlicensed) medical practitioner through most or all of these phases.

A more tangible, if elusive, part of that bequest of knowledge from Matthieu to François took the form of books. Whether Matthieu bequeathed his entire library to his son is not known. Matthieu had made it available at one point to his fellow Protestant, Hebraicist and former Vatable pupil Jean Mercier, but the latter had died in $1570 .{ }^{20}$ One volume still in François's possession at the end of his life, in 1626, almost certainly came from his father: the first edition of Matthieu's magnum opus, the Chronicum, Scripturae sacrae autoritate constitutum (1575). ${ }^{21}$ Others probably did too. ${ }^{22}$ As within many families, the books bequeathed were assets that functioned not as potentially realizable monetary value, but as tools that could generate further kinds of value, some of them plainly financial, and many of them (such as intellectual) potentially contributing to what one can broadly call social status. In functional terms, though not in scale or nature, books were thus analogous both to the tools that artisans bequeathed to their children and even to the estates that nobles bequeathed to theirs. No doubt like some artisanal tools, written works (especially unprinted ones) could require further polishing and improvement by the inheritor: and it may be that Matthieu left papers to François that either he (Matthieu) or others expected François to publish, though 
there is no evidence that he did, unless those papers made their way in unacknowledged form into some of François's own published works. ${ }^{23}$

The learning and, to a lesser extent, the books that Matthieu gave François provided the latter with a vast stock of resources, partly material but largely mental, upon which to draw in his attempts to earn a living and carve out social status. To uncover the full scope of that bookish 'inheritance' (understood largely in a loose, non-legal sense) would require a separate study that would go beyond the question of social status, so let me give just a few initial indications here. The most obvious concern chronology, the subject for which Matthieu became best known. Without mentioning his father, François amplified in more popularizing, vernacular form certain issues that his father had discussed in his magnum opus, such as the prophecies attributed to Elijah to the effect that the world would last for three periods of 2,000 years each; ${ }^{24}$ and François reiterates his father's refutation of the theory that two of the rivers in Eden ('Gehon' and 'Fison') were the Nile and Ganges. ${ }^{25}$ On the other hand, a less obvious field of intellectual inheritance was probably that of Aristotelianism. Although Aristotelianism was still the staple of education in arts faculties and although François was interested in non-Aristotelian philosophies too, he may well have derived especially from his father his intense interest in some dimensions of Aristotelian philosophy, such as demonstration and proof (still ubiquitous in Le Palais des curieux of 1610): for example, Matthieu's inaugural course of lectures at the Genevan Academy was on the Organon. ${ }^{26}$ This learning did not contribute in the same way to the social status of father and son. In Matthieu's case, it contributed to his standing as an institutionally validated authority on argumentation in Latin; in François's, it contributed to his attempt to establish quasi-noble status for himself based on a more individualistic and self-consciously charismatic manipulation of knowledge in the vernacular. The focus on certain branches of Aristotelianism may have been inherited by François not only from his father but ultimately 
from the latter's father-figure, Vatable, who was a specialist not only in Hebrew but also in Greek, and in particular in Aristotle's natural philosophy. ${ }^{27}$ Vatable published (in 1535) translations into Latin of Aristotle's De generatione et corruptione and Parva naturalia, many of the topics of which (ranging from elemental change to the soul and dreams) François popularized and developed in the vernacular, first systematically and then less so, throughout his career, while also lacing them with elements from non-Aristotelian traditions. ${ }^{28}$

The learning that Matthieu transmitted directly or indirectly to his son was intended, in the terms used by Matthieu in his testament to help François better serve God and His Church. Unlike Vatable in his will (intended to help Matthieu acquire medical learning), Matthieu gives no clue whether he also hoped that it would affect the social status of the young man concerned (in this case François). Whether or not Matthieu had aspirations that it would, François used his father's scholarly inheritance to mould his own status in ways that Matthieu could surely not have anticipated. In some respects they even involved disputing or parodying his father's legacy. The fifty-six-year-old François's self-presentation in his miscellany Le Palais des curieux (1612) as a quasi-noble free spirit - beholden to no patron, institution, or customary opinion - includes a claim that the times in which he lives are old whereas antiquity was young (because closer to the world's beginning). In fact, exactly the opposite had been argued by his chronologer father. Worse still, François was tacitly siding with his father's arch-critic Joseph Scaliger. ${ }^{29}$

Or again, when François took still further his critique of 'the learned' ('les doctes'), ${ }^{30}$ publishing anonymously Le Moyen de parvenir (c. 1616), which can be interpreted as associating dignity with a kind of satirical wisdom (implicitly attributed to the author) rather than with clerical, financial, legal, or professorial office, ${ }^{31}$ François began the whole work with a parody of his long-dead father's magnum opus, of which, as we have seen, he had a copy at home: 
Car est il, que ce fut au temps, au siecle, en l'indiction, en l'Aere, en l'Hegire, en l'hebdomade, au lustre, en l'Olimpiade, en l'an, au terme, au mois, en la sepmaine, au jour, à l'heure, à la minute, \& justement à l'instant, que par l'avis \& progrez du Daimon des spheres les esteufs descheurent de credit, \& qu'au lieu d'eux furent auancees les molles balles [...]. ${ }^{32}$

This dating of the replacement of hard by soft balls in real tennis precisely echoes the terms that had been discussed at length by Matthieu - indictio, aera, hegira, hebdomada, Olympiades, annus, mensis, septimana, dies and hora. ${ }^{33}$

More generally, the title-page and opening pages of Le Moyen de parvenir parody the stark claims made by Matthieu in the Chronicum, including on its title-page, to have replaced longstanding controversies with proofs of demonstration that are impervious to questioning:

Matth. Beroaldi Chronicum, [...]. Habes hoc commentario, lector candide, temporum rationem, in qua explicanda plurimi laborarunt, sic expressam et demonstratam, ut de ea posthac nulla sit movenda quaestio. Quandoquidem certis \& indubitatis Scripturae sacrae testimoniis, singula quae hic traduntur, ita sunt confirmata, ut nihil sentire, qui contrà sentiant, videri possint.

The Chronicum of Matthaeus Beroaldus, [...]. Honest reader, you will find in this commentary the calculation of time - which many people have sought to explicate - now so clarified and demonstrated that it will not require future debate. Indeed everything that is communicated here is so confirmed by the certain and indubitable witness of Holy Scripture that those who think differently may be considered to think nothing at all.

This is rewritten on the title-page of Le Moyen de parvenir, with 'ratio' becoming 'raison', 'demonstratam' becoming 'demonstrations', and 'certis' becoming 'certaines' within the totalizing chronological sweep: 'Oeuvre contenant la raison de tout ce qui a esté, est, $\&$ sera: avec demonstrations certaines \& necessaires'. And Matthieu's claim to short-circuit debate is echoed within François’s work: ‘CE MOYEN DE PARVENIR, unique breviaire de resolutions universelles, et particulieres: à quoy on ne peut contredire, ny opposer d'hyperboles, ny le redarguer de fausseté'. ${ }^{34}$ The point of the parody is not just epistemological and psychological, though no doubt it was both. Epistemologically, Matthieu was famous for radically insisting that only chronological knowledge drawn from the Bible is 
valid, for following that method through systematically, and for not shrinking from its consequences, ${ }^{35}$ whereas François had by now for twenty years been questioning systematic approaches to knowledge. ${ }^{36}$ Psychologically, what evidence we have suggests that Matthieu could be a tough and strong character and François a rebellious one, ${ }^{37}$ even if the complexities of their relationship remain forever inaccessible. But the point of the parody is also social, since it targets the institutionalized authorizing of magisterial certainty. Matthieu's preface to the reader of the Chronicum was entitled 'Matthaei Beroaldi, bonarum literarum et philosophiae Christianae professoris, praefatio' ('Preface of Matthaeus Beroaldus, Professor of bonae litterae and Christian philosophy'). The 1575 publication was authorized by the fact that the Geneva Academy had recently bestowed this title on its author. Its folio format contributed to the authorizing. By contrast, the duodecimo Le Moyen de parvenir, the satirical contents of which meant that not only the author but even the printer went unmentioned, was not authorized by any institution, and we now know that its author does seem to have had, at the time of publication, a rather heterogeneous, free-floating social status in comparison with his father's.

These social, epistemological and psychological dimensions are inseparable. Although François may seem to have rejected at least some of what his father transmitted to him, even the act of doing so fuelled his own somewhat different (though roughly equivalent) and more elusive social status, reliant as it was upon witty critique. Like his father, François remained 'above' straightforward artisans (such as Matthieu's own father) and merchants (such as Matthieu's father-in-law) but 'below' straightforward nobles.

Apart from learning, literature, books, an artisanal outlook and some modest financial or other assets, did Matthieu transmit to François anything else that had effects, intended or unintended, on his social status? One crucial thing was a network of contacts, in particular of people who shared a sense that learning and literature should translate into social status. This 
network meant that, compared with someone emerging ex nihilo into the social world, François could, as Matthieu's son, expect to receive from many people recognition, support and opportunities to earn income in the absence of assets of his own (after he had given his inheritance to his sisters). Matthieu had already started building that network when François was a baby, as the choice of godparents shows. ${ }^{38}$ The network facilitated François's first appearance in print, when he supplied the mathematical commentaries for a posthumous edition of what became a bestselling collection of mechanical inventions by the engineer Jacques Besson, who had been a colleague of François's father Matthieu at the University of Orléans. ${ }^{39}$ And, as Stephen Bamforth has shown, it was almost certainly this paternal network that led to François's obtaining from about 1583 the patronage of René Crespin, sieur du Gast. He was the brother-in-law of the same Pierre de l'Estoile who had lived with François's family when a pupil of Matthieu. L'Estoile also probably helped François secure a privilège for his first major solo publication (the 1583 Apprehensions spirituelles collection) ${ }^{40}$

François does not however represent the network as being uniformly supportive. In one case it transmitted not only connections but a feud. If François was the sort of person whom the greatest French scholar of the day, Joseph Scaliger, looked up when passing through Tours on the way to the Estates General in Paris in early 1593, that was because Scaliger had personally known François's father Matthieu. Scaliger had also, however, disliked both Matthieu and his principles of chronology. ${ }^{41}$ The encounter in Tours added a new grievance to the feud: Scaliger's alleged forgetting to honour a promise to return a precious volume that François had lent to Scaliger on that occasion. The ensuing resentment rumbled on for years, with François waiting until Scaliger had died (in 1609) before starting to denounce this behaviour in print. ${ }^{42}$

It is unknown whether it was thanks to the network inherited by François, or to his own networking, or else to a combination of the two, that he became canon in 1593 at the 
Saint-Gatien cathedral of Tours. ${ }^{43}$ This was probably the firmest ever single step up the social ladder that he took in his life, although it did not end up being the first step to higher ecclesiastical office that it was for many sons of high-ranking families. ${ }^{44}$ It did give him, for a while, a coveted prebend in one of the richest cathedral chapters in France, alongside especially the sons of office-holding and wealthy merchant families. ${ }^{45}$ His father's name may have had nothing directly to do with this elevation. It may even have been an obstacle, since Matthieu had been a well-known Calvinist and François had only become eligible for such a position by converting to Catholicism at some point during the $1580 \mathrm{~s} .{ }^{46}$ However, beneath that discontinuity of confession was an inherited continuity of function: François's quasigrandfather had also been a cleric and, although François's father Matthieu's main function in Geneva had been that of a professor, Matthieu may have been a minister there too. ${ }^{47}$ François was probably a secular canon rather than a regular one, and there is no positive indication that he was ordained priest (as his father's ersatz father Vatable had been), but even if he was not, as a cleric in minor orders, he was committed to remaining unmarried in order to receive his prebend. ${ }^{48}$ So, unlike François's Calvinist father, by being a Catholic cleric François was, like Vatable, gaining the chance to have income and so the freedom to pursue learning and/or literature, but at the expense of any chance of bequeathing it to any legitimate offspring. Vatable had circumvented that impasse by bequeathing learning to a young relative. François did not circumvent it. Whatever the nature of his personal life, which is unknown, he seems to have had no children, legitimate or otherwise. ${ }^{49}$ He may have remained unmarried out of preference or else because his economic situation was at different times (i) more unstable than his frequently salaried father's and (ii) stabilized by an office that excluded marriage. Although learning- and blood-based lineage had some importance for Matthieu - at least in relation to his only surviving son (none of Matthieu's daughters are 
known to have been educated) - that son continued it only in a way that precluded its continuation after his own death.

The nexus of education (essentially humanist, but also perhaps latently artisanal), books, reputation and contacts that Matthieu transmitted to François probably proved far more important to the latter's social status and writing career than was any transmission of material wealth. However, vital as that nexus was, it provided as much for François to react against as to build on. And the ways in which he did draw on it ruled out any further extension of this three-generation dynasty of learning and literature (if one counts François's quasi-grandfather Vatable). Theirs was one of numerous short-lived dynasties of literature and learning which cropped up in early modern France, with long-lived ones (such as the Sainte-Marthe) being the exception rather than the rule.

\footnotetext{
${ }^{1}$ On Vatable, Matthieu and François, see V.-L. Saulnier, 'Étude sur Béroalde de Verville: Introduction à la lecture du Moyen de parvenir', Bibliothèque d'Humanisme et Renaissance, 5 (1944), 209-326. On Vatable, see Dick Wursten, 'François Vatable, So Much More Than a "Name", Bibliothèque d'Humanisme et Renaissance, 73:3 (2011), 557-91. For Matthieu's name change, see his testament, in the collection of his papers in the Bibliothèque nationale de France, Mélanges littéraires et historiques [Manuscrits Dupuy], vol. 630, sigs $157^{\mathrm{r}}-82^{\mathrm{v}}<$ http://gallica.bnf.fr/ark:/12148/btv1b54100412j/f323.image> [accessed 27 April 2017] at $157^{\mathrm{v}}$.

${ }^{2}$ Matthieu Beroald, testament, sig. $157^{\mathrm{r}}$.

${ }^{3}$ A notarial act to this effect (Archives Nationales: Y 125, fol. $50^{v}$ ) is reported by Saulnier ('Étude', p. 224).

${ }^{4}$ See Stephen Bamforth, 'Béroalde de Verville and Les Apprehensions spirituelles', Bibliothèque d'Humanisme et Renaissance, 56:1 (1994), 89-97; François Béroalde de
} 
Verville, Les Apprehensions spirituelles, poemes et autres oeuvres philosophiques (Paris:

Timothée Joüan, 1583), sig. ã iiir .

${ }^{5}$ Beroald, testament, sig. $157^{\mathrm{r}}$.

${ }^{6}$ Registres de la compagnie des pasteurs de Genève, ed. by Jean-François Bergier et al.

(Geneva: Droz, 1962- ), IV (1575-82; ed. by Olivier Labarthe and Bernard Lescaze, 1974), p. 91 .

${ }^{7}$ See Stephen Bamforth, ‘Autour du manuscrit 516 du Wellcome Institute de Londres: quelques réflexions sur Béroalde de Verville, médecin et alchimiste', in Béroalde de Verville 1556-1626 (Paris: Presses de l'École Normale Supérieure, 1996), pp. 41-56 (pp. 45-7). Others have speculated both that François studied at medicine at Geneva and also that he obtained a doctorate in medicine there: while the former is possible, the latter seems very unlikely. See Saulnier, 'Étude', p. 219; Ilana Zinguer, 'Verville médecin', in Béroalde de Verville 1556-1626, pp. 25-39 (p. 25).

${ }^{8}$ Vatable's testament stated: 'Item, donne à maistre Mathieu Bérouart toute sa librairie, de quelque profession qu'elle soit, et oulstre ce luy donne [...] cent escuz d'or soleil pour se faire passer docteur en médecine, laquelle somme led. testateur ne veult estre distribuée toute à une foys, ains prie ses exécuteurs tenir la main qu'il ne l'expose inutillement'. Ernest Coyecque, Recueil d'actes notariés relatifs à l'histoire de Paris et de ses environs au XVI siècle, 2 vols (Paris: Imprimerie Nationale, 1905-23), II, no. 4388.

${ }^{9}$ François Béroalde de Verville, Le Palais des curieux, ed. by Véronique Luzel (Geneva: Droz, 2012), object 18. See Stephen Bamforth, 'Grivoiserie et science chez Béroalde de Verville: autour de l'abstinente de Confolens', in Rire à la Renaissance: colloque international de Lille, Université Charles-de-Gaulle-Lille III, 6-8 novembre 2003, ed. by Marie Madeleine Fontaine (Geneva: Droz, 2010), pp. 301-24. On medical and iatrochemical 
themes in works he published between 1583 and 1612, see Luzel's introduction to Le Palais des curieux, pp. 30-3.

${ }^{10}$ See Étienne de Clavière's commentary on Persius in A. Persii Flacci Satyrarum sex liber singularis (Paris: Robert Foüet, 1607), p. 131: 'F. Beroaldus vir insignis, Doctor medicus, meus olim condiscipulus'. For fellow Paracelsian Gabriel de Castaigne calling François a physician and/or a doctor of medicine, see Bamforth, 'Autour du manuscrit 516', pp. 51, 52, 53, 55; François Secret, 'Claude Barthélemy Morisot, chantre de Rubens et romancier chymique', Studi francesi, 16 (1970), 77-85 (p. 82). On Clavière and Castaigne, see Laurence Brockliss and Colin Jones, The Medical World of Early Modern France (Oxford: Clarendon Press, 1997), pp. 124-5.

${ }^{11}$ See Brockliss and Jones, The Medical World, pp. 87, 198-200.

${ }^{12}$ See Idelette Ardouin-Weiss, with the collaboration of Pierre Aquilon, 'Béroalde de Verville: testament inédit et documents nouveaux', Bulletin de la Société de l'Histoire du Protestantisme français, 132 (Oct.-Dec. 1986), 519-40 (pp. 520, 539).

${ }^{13}$ See Ardouin-Weiss, 'Béroalde de Verville', p. 522. No mention of law studies is made by Saulnier ('Étude'). Although François refers at one point in Le Palais des curieux to 'ma qualité d'Advocat', and although a recent editor grants this claim literal force, it seems rather to be playful and entirely metaphorical: Verville, Le Palais des curieux, ed. by Luzel, pp. 314, 469.

${ }^{14}$ Verville, Le Palais des curieux, ed. by Luzel, p. 353. The passage in question is quoted and discussed in Bamforth, 'Béroalde de Verville', p. 45.

${ }^{15}$ See Neil Kenny, The Palace of Secrets: Béroalde de Verville and Renaissance Conceptions of Knowledge (Oxford: Oxford University Press, 1991), pp. 65-6. François gives mechanics prominence in the very first sentence of his testament, regretting that he can no longer practice the 'belles occupations mechaniques' he pursued in his prime. See Ardouin-Weiss, 
'Béroalde de Verville', pp. 523-4; Lenita Locey, Michael Locey and Janis L. Pallister, 'The Last Days of Beroalde de Verville', Symposium, 41 (1987), 42-66 (p. 44). He presents his writing as artisanal labour in the preface ('Advis') to Le Palais des curieux (ed. by Luzel, pp. 133-4).

${ }^{16}$ See Bamforth, 'Scientific and Religious Aspects', pp. xii-xviii; Verville, Le Palais des curieux, ed. by Luzel, pp. 133, 391-3. On the likely influence of Paracelsus (and Theodor Zwinger) on François's injunction to ground speculation in experience, see Didier Kahn, Alchimie et paracelsisme en France (1567-1625) (Geneva: Droz, 2007), pp. 331-3. François's determination to connect manual to learned knowledge seems to have stood out at the time and to have involved a crossing of social boundaries which provoked suspicion: writing five or more years after François's death (1626), Guillaume Colletet reported that François frequented dens of iniquity with low-born people on the pretext of learning specialist artisan terminology. Guillaume Colletet, 'François de Beroalde, sieur de Verville', in Colletet, Vies des poètes tourangeaux, ed. by Lenita Locey, Michael Locey and Janis L. Pallister (Papers on French Seventeenth Century Literature (Paris, Seattle, Tübingen: 1989)), pp. $17-40$ (p. 22).

${ }^{17}$ See François Béroalde de Verville, L'Idee de la republique (Paris: Timothée Joüan, 1584), sig. 70; Verville, Le Palais des curieux, ed. by Luzel, pp. 342-3.

18 'la pauvreté qui l'accabloit': Colletet, 'François de Beroalde', p. 20. Colletet may be taking his cue partly from François himself, who ends his final discursive work by saying that friends have given him financial support, which he needed because patrons exploited him without recompense: Le Palais des curieux, ed. by Luzel, p. 437.

${ }^{19}$ See Bamforth, 'Béroalde de Verville', pp. 51-6; Neil Kenny, 'Béroalde de Verville, François', in Dictionnaire des philosophes français $d u X V I I^{e}$ siècle: acteurs et réseaux $d u$ savoir, ed. by Luc Foisneau, with the collaboration of Elisabeth Dutartre-Michaut and 
Christian Bachelier, 2 vols (Paris: Classiques Garnier, 2015), I, pp. 255-60; Luzel's introduction in Verville, Le Palais des curieux, ed. by Luzel, pp. 13-21; Saulnier, 'Étude', pp. 220-39.

${ }^{20}$ See Wursten, 'François Vatable', p. 560, note 7.

${ }^{21}$ Listed in the inventory of François's library that was drawn up shortly after his death. Although the date of the edition is not mentioned, the indication that it is a folio volume points to the first edition. See Ardouin-Weiss, 'Béroalde de Verville', p. 535; Locey, Locey and Pallister, 'The Last Days', p. 54.

${ }^{22}$ For example, an edition of the Bible in Hebrew, which is probably Vatable's 1539-43 edition of the Hebrew books of the Bible, and possibly Vatable's own copy; Nicolas of Lyra's Hebraicizing commentary on the Bible, which had influenced Reformers; one of the Reformer Sébastien Castellion's translations of the Bible; a volume on surgery, which could have once belonged to François's grandfather Simon Brouart. See Ardouin-Weiss, 'Béroalde de Verville', pp. 532-4; Locey, Locey and Pallister, 'The Last Days', pp. 47, 54-5.

${ }^{23}$ After mentioning the Chronicum, La Croix du Maine speculated as follows in the posthumous entry for Matthieu in his bibliographical catalogue: 'Quant à ses compositions Françoises, tant sur la Theologie que sur les Mathematiques ou l'histoire, elles ne sont encores en lumiere, \& s'il y en a quelques-unes, je m'asseure que le sieur de Verville son fils les publiera pour l'honneur de son pere'. François Grudé de La Croix du Maine, Premier volume de la Bibliotheque (Paris: Abel L'Angelier, 1584), p. 316.

${ }^{24}$ Matthieu Beroald, Chronicum, Scripturae sacrae autoritate constitutum ([Geneva]: Antoine Chuppin, 1575), pp. 63-6; Verville, Le Palais des curieux, ed. by Luzel, pp. 432-5. An indication of how directly François's discussion related to his father's is given by the fact that, over a century after its publication, Matthieu's was still cited as fundamental by Pierre Bayle (Dictionnaire historique et critique, 16 vols (Paris: Desoer, 1820), VI, p. 117). 
${ }^{25}$ Beroald, Chronicum, pp. 81-8; François Béroalde de Verville, Le Cabinet de Minerve (Paris: Sébastien Molin, 1596), sigs 50-2r. See Kenny, The Palace of Secrets, p. 63. ${ }^{26}$ See Registres de la compagnie des pasteurs, ed. by Bergier et al., III (1565-1574; ed. by Olivier Fatio and Olivier Labarthe, 1969), p. 144, note 2. A manuscript by Matthieu on the Organon and Physics, that he presented to his pupil Pierre de l'Estoile, has been discovered by Tom Hamilton, who has kindly alerted me: Bibliothèque Municipale d'Amiens: ms. 506, fols $123^{\mathrm{r}}-86^{\mathrm{v}}$.

${ }^{27}$ See Wursten, 'François Vatable', p. 570.

${ }^{28}$ Most systematically in the Apprehensions spirituelles collection (1583), but also thereafter: see Bamforth, 'Scientific and Religious Aspects'; Kenny, The Palace of Secrets, pp. 63-4, 69-70, 252-8. The indebtedness of François Béroalde de Verville's work to Vatable's would repay study.

${ }^{29}$ Beroald, Chronicum, pp. 179-86; Verville, Le Palais des curieux, ed. by Luzel, pp. 225-6. See Anthony Grafton, Joseph Scaliger: A Study in the History of Classical Scholarship, 2 vols (Oxford: Oxford University Press, 1983-93), I: Textual Criticism and Exegesis, p. 211; Kenny, The Palace of Secrets, p. 226; W. Von Leyden, 'Antiquity and Authority: A Paradox in the Renaissance Theory of History', Journal of the History of Ideas, 19 (1958), 473-92. ${ }^{30}$ The full title of the 1612 miscellany Le Palais des curieux states that it is written partly for 'le plaisir des doctes', to whom François's attitude throughout the work is however ironically deferential and even combative. He refers to this attitude as one of 'liberté': see Neil Kenny, ““Car le nom mesme de libéralité sonne liberté”: les contextes sociaux et économiques du savoir chez Béroalde de Verville', in Béroalde de Verville 1556-1626, pp. 7-24 (pp. 18-20). ${ }^{31}$ The work is generally scathing about office-holders. Satire of legal officers for perjuring themselves when taking the traditional oath that they did not purchase their office is given particular prominence by being put in the mouth of the interlocutor called 'BEROALDE', on 
the sole occasion when he appears. François Béroalde de Verville, Le Moyen de parvenir, ed. by Hélène Moreau and André Tournon, with the collaboration of Jean-Luc Ristori, 2 vols (Paris: Honoré Champion, 2004), II: Fac Simile, p. 198 (original pagination, p. 354). This oath had indeed come to seem so structurally dishonest that it had been discontinued in the years just before Verville was writing. See Arlette Jouanna, La France au XVI siècle, 14831598 (Paris: Presses Universitaires de France, 1996), pp. 210-11. Without clearly replacing venal office-seeking with any other 'moyen de parvenir', François also fleetingly proposes a more spiritual route, writing of Jesus Christ: 'il n'y a que les pauvres femmes qui l'ont pleuré, \& ainsi ont trouvé le moyen de parvenir'. Verville, Le Moyen de parvenir, ed. by Moreau and Tournon, II: Fac Simile, p. 81 (original pagination, p. 110).

${ }^{32}$ Verville, Le Moyen de parvenir, ed. by Moreau and Tournon, II: Fac Simile, p. 26 (original pagination, p. 1).

${ }^{33}$ See Beroald, Chronicum, I.1 ('De Tempore'), I.3 ('De [...] horis'), I.4 ('De Diebus [...]'), I.5 ('De Septimana, sive Hebdomada'), I.6 ('De Mensibus [...]'), I.7 ('De Anno [...]'), II.2 ('De Olympiadibus [...]'), IV.4 ('De A.ER.A.[,] Indictione, \& Hegira.'). This similarity is noted in passing by Janis Pallister, The World View of Béroalde de Verville (Expressed Through Satirical Baroque Style in 'Le Moyen de parvenir') (Paris; J. Vrin, 1971), p. 96. ${ }^{34}$ Verville, Le Moyen de parvenir, ed. by Moreau and Tournon, II: Fac Simile, pp. 25 (titlepage in original), 46-7 (original pagination, pp. 41-2). See also more generally pp. 45-52 (original pagination, pp. 39-54).

${ }^{35}$ See Anthony Grafton, Joseph Scaliger: A Study in the History of Classical Scholarship, II: Historical Chronology, pp. 233, 268-9, 308-11; C. Philipp E. Nothaft, Dating the Passion: The Life of Jesus and the Emergence of Scientific Chronology (200-1600) (Leiden and Boston: Brill, 2012), pp. 271, 283.

${ }^{36}$ See Kenny, The Palace of Secrets, chaps 3-6. 
${ }^{37}$ Beyond the impression of an uncompromising intellect that emerges from Matthieu's Chronicum (when compared with other approaches to chronology in the period), evidence of toughness emerges - with a consistency that perhaps belies the unreliability of the genre of the anecdote - from anecdotes about his life, such as his outburst in Sedan against François ${ }^{\text {er }}$ or his leadership at the siege of Sancerre, when he allegedly stood out for his wise and courageous counsel which led to a policy that those who insisted on surrendering to the besieging Catholic forces should be tossed over the city walls: Agrippa d'Aubigné, Histoire universelle, ed. by André Thierry, 11 vols (Geneva: Droz, 1981-2000), IV, p. 40. See also III, pp. 400-1. As for François, the impression of rebelliousness that emerges from Le Moyen de parvenir echoes the disciplinary conflicts he experienced in his youth in Geneva and the claims about transgressive behaviour made by Colletet in his Life of François, although those claims may themselves be conditioned to some extent by the scabrous nature of François's most famous work, Le Moyen de parvenir.

${ }^{38}$ Jean Mercier, Royal Professor of Hebrew, and Louis Chesneau, Principal of the College of Tours. Matthieu Beroald, family book, in Mélanges littéraires et historiques, vol. 630, sig. $176^{\mathrm{r}}$. See Saulnier, 'Étude', p. 213.

${ }^{39}$ See Saulnier, 'Étude', pp. 213-14. On this work and its long-term significance, see Luisa Dolza and Hélène Vérin, 'Figurer la mécanique: l'énigme des théâtres de machines de la Renaissance', Revue d'histoire moderne et contemporaine, 51:2 (2004), 7-37; Eugénie Droz, Chemins de l'hérésie: textes et documents, 4 vols (Geneva: Slatkine, 1970-6), IV, pp. 271374; Denise Hillard, 'Jacques Besson et son Théâtre des instruments mathématiques', Revue française d'histoire du livre, 48:22 (1979), 5-38; Denise Hillard, 'Jacques Besson et son Théâtre des instruments mathématiques. Recherches complémentaires', Revue française d'histoire du livre, 50:30 (1982), 47-69. Droz misattributes François's commentaries to someone else (François Beraud). 
${ }^{40}$ See Bamforth, 'Béroalde de Verville', pp. 92-4; Saulnier, 'Étude', p. 226.

${ }^{41}$ See Grafton, Joseph Scaliger, II, pp. 70, 246, 268-9, 274-5, 308-11, 343-5.

${ }^{42}$ The first denunciation came in 1612 in Le Palais des curieux (ed. by Luzel, p. 436), where François claims that it was 'un livre imprimé à la Chine dont j'ay encores quelques memoires pour le deschifrer' and that several learned witnesses who were present reported the lending to 'monsieur Servin qui sçait bien d'où j'ay peu avoir un tel joyau, comme d'autres que j'ay perdus par les communs malheurs'. The scholar Louis Servin was an avocat in the Parlement of Tours. The second denunciation came in c. 1616 in Le Moyen de parvenir (ed. by Moreau and Tournon, II: Fac Simile, p. 170 (original pagination, p. 299), where a story about the epithet 'putain' (whore) given to a Queen of Mesopotamia (an apparent allusion to Semiramis) is attributed to 'Barlaam en ses etymologies, imprimees avant mille sans en la Chine. Nostre hoste \& bon ami en presta le livre à Scaliger, quand il passa par Tours' ${ }^{43}$ According to Nicéron, the cathedral register shows François being received as canon on 3 November 1593: Jean Pierre Nicéron, Mémoires pour servir à l'histoire des hommes illustres dans la république des lettres, 43 vols (Paris: Briasson,1727-45), XXXIV, pp. 22438 (p. 225). Colletet ('François de Beroalde', pp. 22-3) confirms that François was a canon at Saint-Gatien, and adds that he eventually gave up this benefice. The latest date at which he is known still to have been a canon is 1602 (thanks to a notarial act that identifies him as such), but thereafter he dropped the title, including in his will, which suggests that Colletet is right that François no longer held this office. See Ardouin-Weiss, 'Béroalde de Verville', p. 520.

On the other hand, there do not seem grounds for doubting whether he was ever a Catholic or canon (as is done by Locey, Locey and Pallister, 'The Last Days', pp. 43-4, 56-9).

${ }^{44}$ See R. Doucet, Les Institutions en France au XVI siècle, 2 vols (Paris: A. and J. Picard, 1948), II, pp. 745-6. 
${ }^{45}$ See Jouanna, La France au XVI ${ }^{e}$ siècle, p. 47. The Council of Trent had decreed that at least 50\% of canons should be priests. See Doucet, Les Institutions, II, p. 739.

${ }^{46}$ See Saulnier, 'Étude', pp. 228-9.

${ }^{47}$ See Eugène Haag and Émile Haag, La France protestante ou Vies des protestants français qui se sont fait un nom dans l'histoire, III (Paris and Geneva: Joël Cherbuliez, 1852), p. 7. Matthieu was a prolific writer of prayers to be said by the guards on watch at the siege of Sancerre: see his papers in Mélanges littéraires et historiques, sigs $144^{\mathrm{r}}-51^{\mathrm{v}}$. According to Nicolas Pithou, in 1570 Matthieu also acted - informally, it would seem - as a minister when he persuaded the ex-bishop Antonio Caracciolo to make a Protestant confession of faith on his deathbed. See Nicolas Pithou, Chronique de Troyes et de la Champagne (1524-1594), ed. by Pierre-Eugène Leroy, with collaboration by Isabelle Palasi, 2 vols (Reims: Presses Universitaires de Reims, 1998-2000), II, pp. 668-70; Joseph Roserot de Melin, Antonio Caracciolo, évêque de Troyes (1515?-1570) (Paris: Letouzey et Ané, 1923), pp. 357, 35960; Thierry Wanegffelen, Ni Rome ni Genève: des fidèles entre deux chaires en France au XVI siècle (Paris: Honoré Champion, 1997), pp. 250-1.

${ }^{48}$ He had bought a house by 1602 and moved into it by 1609, which suggests either that he did not live in the community of canons and/or that he financed the purchase by selling his benefice in about 1602, which may indeed be what Colletet alludes to by accusing François of simony ('se deffit simoniaquement de son bénefice'; Colletet, 'François de Beroalde', p. 23); such sales were common (Doucet, Les Institutions, II, p. 739).

${ }^{49}$ The hypothesis that a reference to a 'jeune Béroalde' in a 1599 publication designates an illegitimate son of his looks tenuous pending further evidence. See Frédéric Lachèvre, Bibliographie des recueils collectifs de poésies publiés de 1597 à 1700, 4 vols (Paris: Henri Leclerc, 1901-5), I, p. 108; Saulnier, 'Étude', p. 239. 